\title{
Water Vapour Weighted Mean Temperature Model for GPS-Derived Integrated Water Vapour in Peninsular Malaysia
}

\author{
Musa, T.A. ${ }^{a}$, Mazlan, M.H. ${ }^{a}$, Opaluwa, Y.D. ${ }^{b}$, Musliman, I.A. ${ }^{a}$ and Radzi Z.M. ${ }^{c}$ \\ ${ }^{a}$ Geomatic Innovation Research Group, Infocomm Research Alliance Faculty of Geoinformation \& Real Estate \\ Universiti Teknologi Malaysia 81310, Johor Baharu Malaysia. \\ ${ }^{b}$ Department of Surveying and Geoinformatics, School of Environmental Technology, Federal University of \\ Technology Minna, Nigeria. \\ ${ }^{c}$ National Space Agency, Ministry of Science, Technology and Innovation, Malaysia Space Centre, 42700 Banting, \\ Selangor, Malaysia.
}

KEY WORDS: Diurnal cycle, Monsoon, GPS Meteorology

\begin{abstract}
:
This paper presents the development of $T_{M}$ model by using the radiosonde stations from Peninsular Malaysia. Two types of $T_{M}$ model were developed; site-specific and regional models. The result revealed that the estimation from site-specific model has small improvement compared to the regional model, indicating that the regional model is adequately to use in estimation of GPS-derived IWV over Peninsular Malaysia. Meanwhile, this study found that the diurnal cycle of $T_{S}$ has influenced the $T_{M^{-}} T_{S}$ relationship. The separation between daytime and nighttime observation can improve the relationship of $\mathrm{T}_{\mathrm{M}}-\mathrm{T}_{\mathrm{S}}$. However, the impact of diurnal cycle to IWV estimation is less than $1 \%$. The $\mathrm{T}_{\mathrm{M}}$ model from Global and Tropic also been evaluated. The Tropic $\mathrm{T}_{\mathrm{M}}$ model is superior to be utilized as compared to the Global $\mathrm{T}_{\mathrm{M}}$ model.
\end{abstract}

\section{INTRODUCTION}

The Global Positioning System (GPS) nominally consists of at least 24 satellites in almost circular orbital planes, with altitudes of about 22,000 kilometres above the Earth's surface. The satellites continuously transmit their signals through the Earth's atmosphere to ground-based receivers and accordingly, the effect of the atmosphere on the propagation of the GPS signal path (or atmospheric delay) provides information about water vapour contents in the atmosphere (Bevis et al., 1992).

The delays were represented as zenith path delay (ZPD) that can be divided into two parts: i) zenith hydrostatic delay (ZHD), which depends only on surface air pressure; and ii) zenith wet delay (ZWD), which is a function of atmospheric water vapour profile (Businger et al., 1996). Information about these delays has enabled the application of GPS for meteorology such as studying diurnal variation in water vapour (see Dai et al., 2002); improving numerical weather prediction (see Gendt et al., 2004) and climate monitoring (see Nilsson and Elgered, 2008). A number of studies have shown that it is offering better spatial distribution, continuous observation, not affected by rainfall and clouds, inexpensive to setup, and a promising tool to complement other remote sensing technique of measuring water vapour content (Ware et al.,2000; Wolfe and Gutman, 2000).

The processes of GPS meteorology, specifically in the estimation of GPS-derived integrated water vapour (IWV) or equivalently precipitable water vapour (PWV), require a fundamental parameter of 'water vapour weighted mean temperature of the atmosphere or TM' since both these IWV and ZWD are interrelated (Wang et al., 2005). A commonly used method to estimate the $T_{M}$ parameter; (1) to apply a regression function from the relationship of surface air temperature (TS) as described by Musa et al., (2011) and Liou et al., (2001), (2) reanalyses the output from numerical weather prediction model such as Jin et al., (2009) and Heise et al., (2009), (3) estimate by using the Global Pressure and Temperature (GPT) model developed by Boehm et al., (2007) (Yao et al., 2012).

The GPS-derived IWV can be written as (Askne and Nordius, 1987);

$$
\mathrm{IWV}=\mathrm{ZWD} / \overline{\mathrm{K}}
$$

and,

$$
\overline{\mathrm{K}}=\frac{10^{6}}{\mathrm{R}_{\mathrm{v}}\left(\frac{\mathrm{k}_{3}}{\mathrm{~T}_{\mathrm{M}}}+\mathrm{k}_{2}^{\prime}\right)}
$$

where $\mathrm{R}_{\mathrm{v}}$ is the gas constant for water vapour, $\mathrm{k}_{3}$ and $\mathrm{k}_{2}$ are the atmospheric refractivity constants (see Thayer, 1974; Bevis et al., 1994). The $\mathrm{T}_{\mathrm{M}}$ in Equation 2 is given by (Wang et al., 2005);

$$
\mathrm{T}_{\mathrm{M}}=\frac{\int\left(\frac{\mathrm{e}}{\mathrm{T}}\right) \mathrm{dz}}{\int\left(\frac{\mathrm{e}}{\mathrm{T}^{2}}\right) \mathrm{dz}} \approx \frac{\sum_{\mathrm{i}=1}^{\mathrm{N}} \frac{\mathrm{e}}{\mathrm{T}}\left(\mathrm{h}_{\mathrm{i}+1}+\mathrm{h}_{\mathrm{i}}\right)}{\sum_{\mathrm{i}=1}^{\mathrm{N}} \frac{\mathrm{e}}{\mathrm{T}^{2}}\left(\mathrm{~h}_{\mathrm{i}+1}+\mathrm{h}_{\mathrm{i}}\right)}
$$

where $\mathrm{T}$ is the surface temperature of the radiosonde profile, $\mathrm{dz}$ is the function of vertical profile that is defined as the geopotential height $\mathrm{h}$ of radiosonde with respect to vertical profile of the surface pressure layer along the troposphere layer and, e is the surface partial pressure of water vapour that can be defined as; 


$$
e=6.107 \times E^{\frac{a \times T_{d}}{b+T_{d}}}
$$

where $T_{d}$ is the dew temperature $[a=21.87$ and $b=265.49$ when $\mathrm{T}_{\mathrm{d}}$ is below $55^{\circ} \mathrm{C}$ or $\mathrm{a}=17.26$ and $\mathrm{b}=237.29$, when $\mathrm{T}_{\mathrm{d}}$ is above $0{ }^{\circ} \mathrm{C}$. Practically, the weighted $\mathrm{T}_{\mathrm{M}}$ parameter can be derived by empirical regression function using the relationship of $\mathrm{T}_{M}$ and $\mathrm{T}_{\mathrm{S}}$;

$$
\mathrm{T}_{\mathrm{M}}=\mathrm{m} \cdot \mathrm{T}_{\mathrm{S}}+\mathrm{c}
$$

where the value of $m$ and $c$ parameters represent the sensitivity of $T_{M}-T_{S}$ relationship. Table 1 list several existing $T_{M}$ models that were developed following equation 5 .

Table 1. The existing $\mathrm{T}_{\mathrm{M}}$ model with the author

\begin{tabular}{llll}
\hline T $_{M}$ model & \multicolumn{1}{c}{ Equation } & \multicolumn{1}{c}{ Author } \\
\hline Global 1 & $\mathrm{T}_{\mathrm{M}}=0.72 \mathrm{~T}_{\mathrm{S}}+70.2$ & $(6)$ & Bevis et al., (1992) \\
Global 2 & $\mathrm{T}_{\mathrm{M}}=0.64 \mathrm{~T}_{\mathrm{S}}+86.9$ & $(7)$ & Schueler et al., (2001) \\
Global 3 & $\mathrm{T}_{\mathrm{M}}=0.8116 \mathrm{~T}_{\mathrm{S}}+43.69$ & $(8)$ & Yao et al., (2014) \\
\hline Tropic 1 & $\mathrm{T}_{\mathrm{M}}=1.07 \mathrm{~T}_{\mathrm{S}}-31.5$ & $(9)$ & Liou et al., (2001) \\
Tropic 2 & $\mathrm{T}_{\mathrm{M}}=0.75 \mathrm{~T}_{\mathrm{S}}+62.57$ & $(10)$ & Suresh Raju et al., (2007) \\
Tropic 3 & $\mathrm{T}_{\mathrm{M}}=0.84 \mathrm{~T}_{\mathrm{S}}+48.103$ & $(11)$ & Wayan et al., (2013) \\
\hline
\end{tabular}

The Global 1 model has been developed by using radiosonde data covering the America region over 2 year period (19901991). The Global 1 model has been widely utilized, especially in GPS-derived IWV such as utilized by Jin et al. (2008); Musa et al., (2011); Xu et al. (2012). However, the Global 1 does not represent the actual climatic condition worldwide. Thus, several efforts have been made to improve the global $\mathrm{T}_{\mathrm{M}}$ model such as demonstrated by Global 2 and Global 3. The Global 2 attempted to cover the whole world by using global scale analysis of numerical weather prediction. Meanwhile, Yao et al. (2014) conducted extensive work to adjust the Global 1 model; 135 globally distributed radiosonde stations was utilized spanning 10 -year period and Global 3 model was realized.

Ross and Rossenfeld (1997) and Wang et al. (2005) have performed the evaluation study on the Global 1 model. In general, both of them found that the Global 1 model is limited especially in the tropics. Ross and Rossenfeld (1997) found that the Global 1 has a systematic warm bias due to the shorter data period used. Wang et al. (2005) found that Global 1 suffer from the cold bias of $1-6 \mathrm{~K}$ in the tropics and sub-tropic. Moreover, the Global 1 also suffer from diurnal cycle about $1-4 \mathrm{~K}$ in morning (00-06 LST) and 3-6 K at night (20-23 LST).

Due to some limitations from these Global models, most of the communities in the tropics have attempted to adapt the Global 1 by using the local or regional radiosonde basis observation to support their regional needs. The Tropic 1 model was developed by using the radiosonde observation at Taipei spanning from year 1988 to 1997 . Tropic 2 model was developed to cover the Indian region using data from year 1995 to 1997. Meanwhile, the Tropic 3 model was developed for Western Pacific region (latitude and longitude range $20^{\circ} \mathrm{N}-20^{\circ} \mathrm{S}$ and $95^{\circ} \mathrm{E}-156^{\circ} \mathrm{E}$ ) from 15 radiosonde stations for whole year 2011. From their results, it was found that the estimation of GPS-derived IWV can be improved by using their own $\mathrm{T}_{\mathrm{M}}$ model rather than Global $\mathrm{T}_{\mathrm{M}}$ model.

Therefore, this study seeks to attempt an estimation of a $T_{M}$ parameter for Peninsular Malaysia with a view to utilizing the estimated $\mathrm{T}_{\mathrm{M}}$ for GPS-derived IWV estimation.

\section{DATA SET: RADIOSONDE AND GPS STATION}

The observation from the radiosonde is the primary data for developing the $\mathrm{T}_{\mathrm{M}}$ model over Peninsular Malaysia. This radiosonde observation is usually carried out by launching helium gas balloon to the upper atmosphere which allow to measure meteorological parameters. The radiosonde is built by a package meteorological sensor for measuring the pressure, temperature, dew point and geo-potential height (Durre et al., 2006).

In Peninsular Malaysia, there are four well distributed radiosonde stations comprising two on the west coast (Sepang (SPNG) and Bayan Lepas (WMKP)) and two on the east coast (Kota Bahru (WMKC) and Kuantan (WMKD)). These radiosonde stations are named according to the World Meteorological Organization (WMO) radiosonde station identifier. In Malaysia, Malaysian Meteorological Department (MetMalaysia) is the responsible agency to operate the radiosonde launches. The MetMalaysia routinely launch the radiosonde balloon twice daily at 00 and 12 UTC (or 8 am and 8 pm local time).

Three years period of radiosonde data from year 2006-2008 have been acquired from MetMalaysia and has been utilized to estimate $T_{M}$ parameter, hence, a local $T_{M}$ model was developed. However, prior to the estimation of the TM parameter, inspection of radiosonde data was conducted to detect missing data and erroneous observations. Thus, the outliers were filtered out and removed from the computation leaving only clean radiosonde data for estimation of the $T_{M}$ parameter and radiosonde-derived IWV for assessment.

In addition, measurements from four (4) GPS continuously operating reference stations (CORS) which are located nearest to these radiosonde stations were also acquired. These GPS CORS (i.e., Pulau Pinang (USMP), Banting (BTNG), Geting (GETI) and Pekan (PEKN)) are part of the Malaysian RealTime Kinematic network (MyRTKnet) which is being maintained by the Department of Survey \& Mapping Malaysia (DSMM). Only GPS data in year 2008 is available for this study and the ZPD parameter from these stations was estimated according to Musa et al., (2011). Figure 1 shows the spatial location of the radiosonde stations and the GPS CORS, while Table 2 lists the site coordinates of each radiosonde station and the GPS CORS respectively. 
Table 2. The coordinates of radiosonde stations and GPS CORS, and the different height and distance between radiosonde station and GPS CORS. Different height between GPS and Radiosonde station can affect the $T_{M}$ if above the $100 \mathrm{~m}$ (Wang et al., 2005).

There is no height extrapolation applied because of the different in height is below than $100 \mathrm{~m}$.

\begin{tabular}{ccc|ccc|cc}
\hline Radiosonde Station & Latitude & Longitude & GPS CORS & Latitude & Longitude & $\Delta \mathbf{H}(\mathbf{m})$ & $\boldsymbol{\Delta D}(\mathbf{k m})$ \\
\hline SPNG & $2^{\circ} 44^{\prime}$ & $101^{\circ} 42^{\prime}$ & BTNG & $2^{\circ} 49^{\prime}$ & $101^{\circ} 32^{\prime}$ & 29.21 & 12.25 \\
WMKP & $5^{\circ} 18^{\prime}$ & $100^{\circ} 16^{\prime}$ & USMP & $5^{\circ} 21^{\prime}$ & $100^{\circ} 18^{\prime}$ & 8.219 & 4.4 \\
WMKC & $6^{\circ} 10^{\prime}$ & $102^{\circ} 17^{\prime}$ & GETI & $6^{\circ} 13^{\prime}$ & $102^{\circ} 06^{\prime}$ & 3.181 & 18.8 \\
WMKD & $3^{\circ} 47^{\prime}$ & $103^{\circ} 13^{\prime}$ & PEKN & $3^{\circ} 29^{\prime}$ & $103^{\circ} 23^{\prime}$ & 4.667 & 37.79 \\
\hline
\end{tabular}

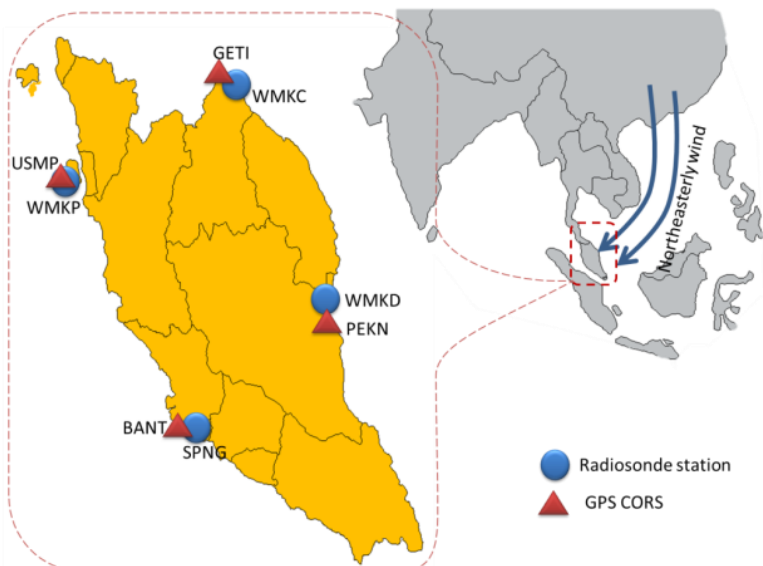

Figure 1. The spatial location of radiosonde station and GPS CORS in Peninsular Malaysia. Right figure shows the northeasterly wind direction flow out from northern hemisphere contribute the variability in $\mathrm{T}_{\mathrm{S}}$ at east coast region (Figure is adapted accordingly Tangang et al., (2008)).

\section{RESULTS - $\mathbf{T}_{M}, \mathbf{T}_{M}-\mathbf{T}_{\mathrm{S}}$ RELATIONSHIP AND DIURNAL CYCLE IN BODY OF TEXT}

\subsection{Estimation of the $\mathbf{T}_{M}$ Parameter}

The filtered and cleaned radiosonde data was used as an input into Equation 3. The result of $T_{M}$ which covers the period 2006 to 2008 is provided in Table 3. Meanwhile, the statistics of $T_{S}$ which was measured at ground surface level at radiosonde station is provided in Table 4 .

Table 3. The statistical result of $\mathrm{T}_{\mathrm{M}}$ for each radiosonde station

\begin{tabular}{lcccc}
\hline Station & Min $(\mathrm{K})$ & Max $(\mathrm{K})$ & Average $(\mathrm{K})$ & Variation $(\mathrm{K})$ \\
\hline SPNG & 283.148 & 294.153 & 287.962 & 1.472 \\
WMKD & 283.473 & 294.647 & 288.331 & 1.522 \\
WMKC & 283.011 & 293.122 & 288.692 & 1.583 \\
WMKP & 283.285 & 293.998 & 288.510 & 1.509 \\
\hline
\end{tabular}

Table 4. The statistical result of $\mathrm{T}_{\mathrm{S}}$ for each radiosonde station

\begin{tabular}{lcccc}
\hline Station & Min $(\mathrm{K})$ & Max $(\mathrm{K})$ & Average $(\mathrm{K})$ & Variation $(\mathrm{K})$ \\
\hline SPNG & 293.75 & 304.55 & 299 & 1.894 \\
WMKD & 293.55 & 304.15 & 298.501 & 2.013 \\
WMKC & 293.122 & 303.75 & 299 & 2.031 \\
WMKP & 295.35 & 303.95 & 299.56 & 1.841 \\
\hline
\end{tabular}

The average of $T_{M}$ over Peninsular Malaysia is almost consistent at all radiosonde stations which range from $287.962 \mathrm{~K}$ to $288.692 \mathrm{~K}$. The annual $\mathrm{T}_{\mathrm{M}}$ gradient is very weak which is below $2 \mathrm{~K}$. This study found similar result with Ross and Rosenfeld, (1997) which conducted a study on the estimation of
$\mathrm{T}_{\mathrm{M}}$ parameter over 23-year period observational data from 53 radiosonde stations of global radiosonde network. They found that the $T_{M}$ at several radiosonde stations close to low-latitude as listed in Table 5 is relatively higher than in Peninsular Malaysia, ranging from about 1-2K. Moreover, Suresh Raju et al., (2007) conducted similar study in Indian region and found that the $\mathrm{T}_{\mathrm{M}}$ at near low-latitude region (e.g. Trivandrum $\left(8.5^{\circ} \mathrm{N}\right)$, Port Blair $\left(11.6^{\circ} \mathrm{N}\right)$, Bangalore $\left(12.9^{\circ} \mathrm{N}\right)$, Kolkata $\left(22.6^{\circ} \mathrm{N}\right)$ and Ahmedabad $\left.\left(23.1^{\circ} \mathrm{N}\right)\right)$ fall between 284.1 to $287.8 \mathrm{~K}$

Table 5. Several selected radiosonde stations utilized by Ross and Rosenfeld, (1997). From 53 radiosonde stations, only 5 stations are located near low-latitude. They did not include any radiosonde station located close to equatorial region such as Malaysia.

\begin{tabular}{cccc}
\hline Location & $\begin{array}{c}\text { Latitude }^{\circ} \mathrm{N}, \\
\text { Longitude }^{\circ} \mathrm{W}\end{array}$ & $\begin{array}{c}\text { Annual } \\
\text { Mean }(\mathrm{K})\end{array}$ & $\begin{array}{c}\text { Variation } \\
(\mathrm{K})\end{array}$ \\
\hline Niger & $13.5,357.8$ & 291.61 & 2.72 \\
Guam & $13.5,215.2$ & 292.74 & 0.52 \\
Hawaii & $19.7,155.1$ & 289.85 & 1.11 \\
India & $21.1,280.9$ & 291.92 & 2.46 \\
Mexico & $20.9,89.7$ & 291.39 & 1.24 \\
Puerto Rico & $18.4,66.0$ & 291.22 & 0.89 \\
\hline
\end{tabular}

* Note that, these values have been corrected after the coding error was discovered in the global analysis (Ross and Rosenfeld, 1999).

The geographical location has the major influence on the variability of $T_{S}$ in Peninsular Malaysia. In low latitude region, the sun's zenith distance remains relatively short throughout the year. Earth's surface absorbs maximum amount of solar radiation from sun compared to middle and high latitudes. Thus, the $\mathrm{T}_{\mathrm{S}}$ remain warmer with values ranging from 298.501 to $299.56 \mathrm{~K}$ at all radiosonde stations in Peninsular Malaysia with less variation of about 1.841 to $2.031 \mathrm{~K}$ throughout the year.

\subsection{Variability of $T_{M}$ and $T_{S}$}

The three years period of radiosonde data (2006-2008) are utilized to observe the variability of $\mathrm{T}_{\mathrm{M}}-\mathrm{T}_{\mathrm{S}}$ in Peninsular Malaysia. Figures 2 (a-d) show the time series of $T_{M}$ and $T_{S}$ at each radiosonde stations.

The time series show that the daily variation of $T_{M}$ and $T_{S}$ are low range $\approx 10 \mathrm{~K}$ and low variation throughout the year (see Table 3 and 4). The climatic characteristic in low latitude is only wet and dried without appearance of the season changes such as in middle-latitudes. The low-latitude atmosphere is relatively warm to support tropical climate and activities. There is no clear appearance of seasonal cycle trend found at all radiosonde stations. 

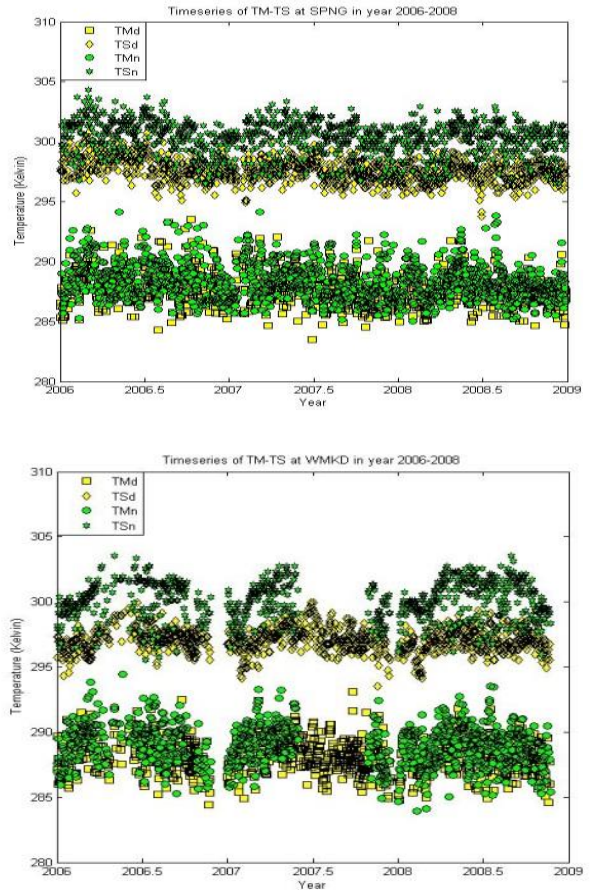
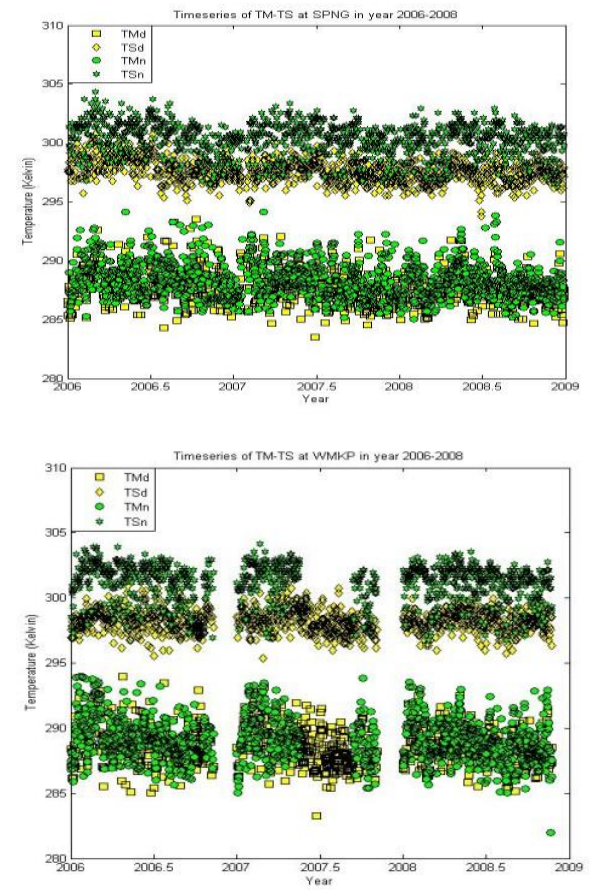

$\mathrm{c}$

$\mathrm{d}$

Figure 2. The time-series of $T_{M}$ and $T_{S}$ at SPNG (a), WMKC (b), WMKD (c) and WMKP (d). The TS is higher about 10K compared to the $\mathrm{T}_{\mathrm{M}}$. From this figure, it can be clearly seen that observed TS at nighttime is higher than daytime. Meanwhile, no different found in $\mathrm{T}_{\mathrm{M}}$ between daytime and nighttime.

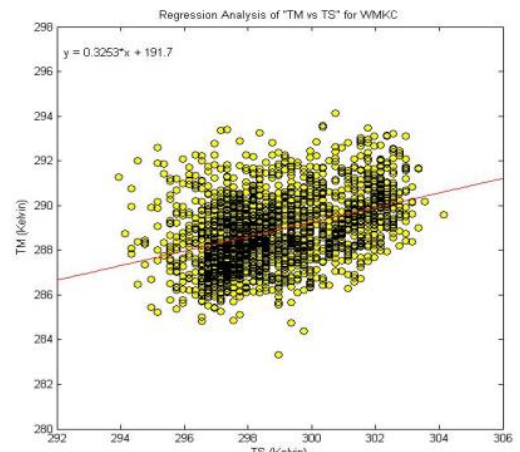

a

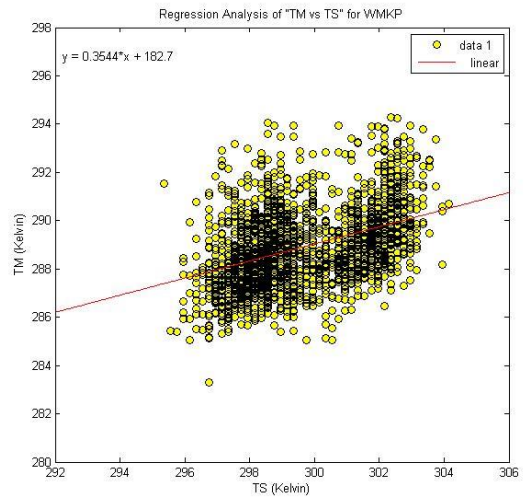

Figure 3. The site-specific $T_{M}$ model for each radiosonde station in Peninsular Malaysia. Scatter plot $T_{M}$ against $T_{S}$ show that the

$\mathrm{T}_{\mathrm{M}}-\mathrm{T}_{\mathrm{S}}$ relationship is $<0.4$ which indicates weak relationship at all radiosonde stations.

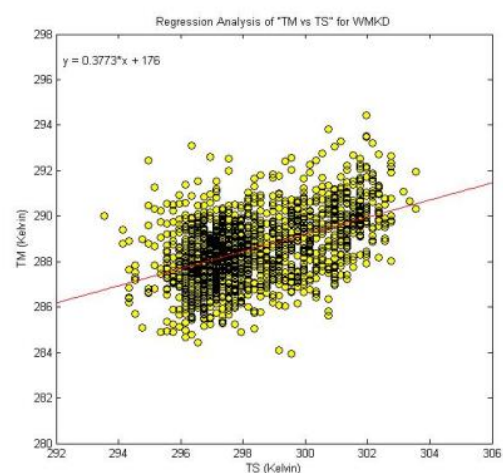

b

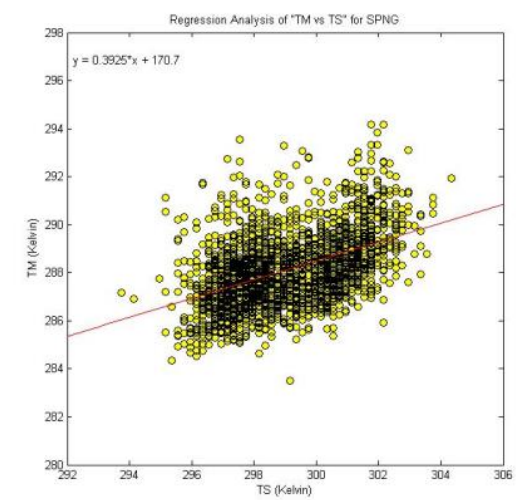

d 
The variability of $T_{S}$ is influenced by monsoon seasons especially, the northeast monsoon (winter monsoon). This event influences the $\mathrm{T}_{\mathrm{S}}$ over the northeast region that can be shown in the scatter plot of Figure 2 (WMKC and WMKD). The $\mathrm{T}_{\mathrm{S}}$ is slightly reduced from November until March. During this period, the cold northeasterly wind from the Siberia flow out towards the coastal waters of southern South China Sea and heading to east coast often brings heavy rainfall to this area (see Figure 1; Tangang et al., 2008; Loo et al., 2014).

In addition, the daily variability on $T_{S}$ occurred between night and daytime. It can clearly be realized the $T_{S} n\left(T_{S}\right.$ night observe at $8 \mathrm{pm}$ LST) is higher with about $3 \mathrm{~K}$ compared to $\mathrm{T}_{\mathrm{S}} \mathrm{d}$ ( $\mathrm{T}_{\mathrm{S}}$ day - measure at 8 am LST). This is because the earth's surface absorbed huge amount of heat from sun in the afternoon $(2 \mathrm{pm}-4 \mathrm{pm}$ LST) and gradually decreases in the evening (Shinoda, 2005). Meanwhile, the diurnal cycle is very weak about $1 \mathrm{~K}$. However, both impacts of monsoon and diurnal cycle is only dominant in $T_{S}$ and not in the $T_{M}$.

\subsection{Linear regression analysis for $T_{M^{-}} T_{S}$ relationship}

The development of $T_{M}$ model which is based on linear regression analysis of $T_{M}-T_{S}$ relationship is essential to allow for the estimation of $T_{M}$ parameter without depending on the radiosonde data (see Figure 4). Such $\mathrm{T}_{\mathrm{M}}$ model can support the estimation of GPS-derived IWV at more frequent up to hourly (as long as the GPS ZPD and $\mathrm{T}_{\mathrm{S}}$ are available) intervals. In the linear regression analysis, the $T_{M}$ is plotted on the $y$-axis, meanwhile the $T_{S}$ is plotted on the $x$-axis. Figures 3 (a-d) shows the scatter plot of $T_{M}$ against $T_{S}$ for each radiosonde stations with 3 years data span (2006-2008).

Equations 12-15 are site-specific $\mathrm{T}_{\mathrm{M}}$ models developed from the regression analysis for each radiosonde station.

$$
\begin{aligned}
& \text { SPNG; } \mathrm{T}_{\mathrm{M}}=0.39 \mathrm{~T}_{\mathrm{S}}+170.7 \\
& \text { WMKC; } \mathrm{T}_{\mathrm{M}}=0.33 \mathrm{~T}_{\mathrm{S}}+191.7 \\
& \text { WMKD; } \mathrm{T}_{\mathrm{M}}=0.38 \mathrm{~T}_{\mathrm{S}}+176 \\
& \text { WMKP; } \mathrm{T}_{\mathrm{M}}=0.35 \mathrm{~T}_{\mathrm{S}}+182.7
\end{aligned}
$$

Most researchers developed the regional $\mathrm{T}_{\mathrm{M}}$ model based on the combination of several observations from radiosonde station within regional scale such as demonstrated by Bevis et al., (1992) in America; Suresh Raju et al., (2007) and Singh et al., (2014) in India. This regional $T_{M}$ model enables the estimation of GPS-derived IWV at all GPS stations within their region without estimate at every site-specific radiosonde station.

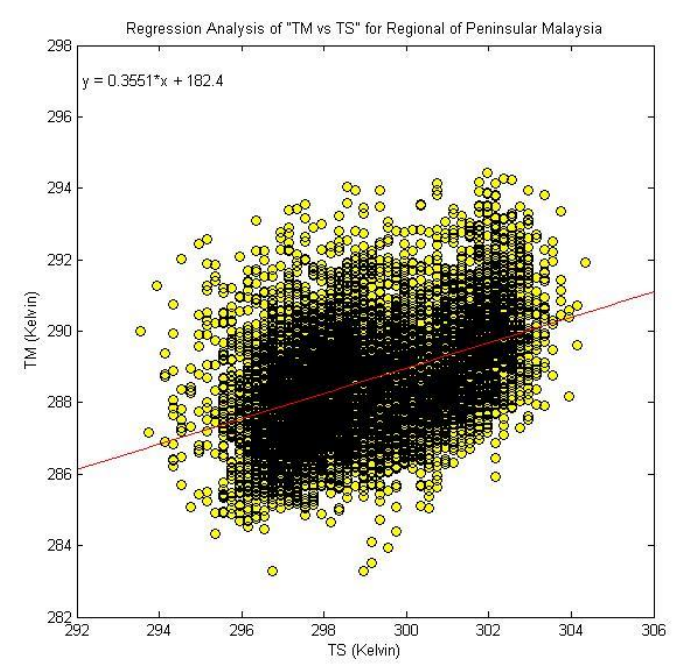

Figure 4. Regional $\mathrm{T}_{\mathrm{M}}$ model is developed by combining all the radiosonde stations over Peninsular Malaysia to form a single equation of linear regression analysis.

In this study, Equation 16 is developed for regional model.

$$
\text { Regional; } \mathrm{T}_{\mathrm{M}}=0.36 \mathrm{~T}_{\mathrm{S}}+182.4
$$

It was revealed that the regression slope and intercept of regression analysis at all radiosonde station in Peninsular Malaysia are between the range of 0.2941 to 0.3759 and 175.6 to 200.4, respectively. This indicates that the relationship of $\mathrm{T}_{\mathrm{M}^{-}}$ $\mathrm{T}_{\mathrm{S}}$ in Peninsular Malaysia has weak correlation. Similar result was found by Ross and Rossenfeld, (1997) in which all tropical radiosonde stations showed weak correlation of about less than 0.5 . For further understanding, this study attempts to investigate the cause of weak correlation of $\mathrm{T}_{\mathrm{M}^{-}} \mathrm{T}_{\mathrm{S}}$ relationship in Peninsular Malaysia.

\subsection{Influence of diurnal cycle in $T_{M}-T_{S}$ relationship}

According to the Figure 2, the variability of $\mathrm{T}_{\mathrm{M}^{-}} \mathrm{T}_{\mathrm{S}}$ is influenced by the diurnal cycle of $T_{M}-T_{S}$. The magnitude of diurnal cycle on $T_{M}$ and $T_{S}$ is different; it is smaller on $T_{M}$ than $T_{S}$. Nevertheless, the variation of $T_{S}$ especially, its large variability contributes weak correlation to the $T_{M}-T_{S}$ relationship. To investigate it, this study designed the temporal analysis for $\mathrm{T}_{\mathrm{M}^{-}}$ $\mathrm{T}_{\mathrm{S}}$ relationship. Two types of linear regression were developed based on observation epochs (i.e. daytime and nighttime observation). Table 6 depicts two epochs of $\mathrm{T}_{M}$ model; daytime and nighttime $T_{M}$ model. The impact of these $T_{M}$ models on GPS-derived IWV was assessed in Section 4.

Table 6. The daytime and nighttime $\mathrm{T}_{\mathrm{M}}$ models have been developed for each radiosonde station. From temporal analysis, it was found that the relationship of $\mathrm{T}_{\mathrm{M}}-\mathrm{T}_{\mathrm{S}}$ is always higher; $>0.5$ for the night observation. Meanwhile, the spatial location also indicates that the $\mathrm{T}_{\mathrm{M}}-\mathrm{T}_{\mathrm{S}}$ daytime has weak relationship at east coast compared to the west coast.

\begin{tabular}{lllll}
\hline Radiosonde Station & Daytime model & & Nighttime model & \\
\hline SPNG & $\mathrm{T}_{\mathrm{M}}=0.51 \mathrm{~T}_{\mathrm{S}}+136.2$ & $(17)$ & $\mathrm{T}_{\mathrm{M}}=0.66 \mathrm{~T}_{\mathrm{S}}+91.8$ & $(21)$ \\
WMKC & $\mathrm{T}_{\mathrm{M}}=0.23 \mathrm{~T}_{\mathrm{S}}+220.5$ & $(18)$ & $\mathrm{T}_{\mathrm{M}}=0.51 \mathrm{~T}_{\mathrm{S}}+135.6$ & $(22)$ \\
WMKD & $\mathrm{T}_{\mathrm{M}}=0.34 \mathrm{~T}_{\mathrm{S}}+186.6$ & $(19)$ & $\mathrm{T}_{\mathrm{M}}=0.62 \mathrm{~T}_{\mathrm{S}}+101.6$ & $(23)$ \\
WMKP & $\mathrm{T}_{\mathrm{M}}=0.49 \mathrm{~T}_{\mathrm{S}}+143.8$ & $(20)$ & $\mathrm{T}_{\mathrm{M}}=0.64 \mathrm{~T}_{\mathrm{S}}+96.9$ & $(24)$ \\
\hline
\end{tabular}

The result shown that serious problem on the relationship $\mathrm{T}_{\mathrm{M}^{-}} \mathrm{T}_{\mathrm{S}}$ is due to the diurnal cycle of $T_{S}$. The variability of $T_{S}$ influenced the sensitivity of $T_{M}-T_{S}$ relationship. The relationship of $T_{M}-T_{S}$ has improved for the nighttime observation from weak correlation (0.3) to moderate correlation $(>0.5)$. However, in the daytime observation, the strength of $\mathrm{T}_{\mathrm{M}}-\mathrm{T}_{\mathrm{S}}$ relationship is 
improved only at west coast radiosonde stations (SPNG and WMKP), without any improvement noticed at the east coast stations (WMKC and WMKD). Thus, the geographical aspect should be considered in $\mathrm{T}_{\mathrm{M}}-\mathrm{T}_{\mathrm{S}}$ relationship.

\section{ASSESSMENT}

This assessment was conducted to validate the accuracy of $T_{M}$ model in Peninsular Malaysia. Only four GPS stations located nearest to the radiosonde stations were utilized in the assessment. One year period of data span which is in whole year 2008 has been processed to estimate the ZPD parameter. This ZPD was processed along with various types of $T_{M}$ model to obtain GPS-derived IWV. Meanwhile, the radiosonde data in year 2008 from all radiosonde stations were also utilized to benchmark the estimation of GPS-derived IWV along with the $\mathrm{T}_{\mathrm{M}}$ model.

Three (3) cases study has been proposed to evaluate the impact of $\mathrm{T}_{\mathrm{M}}$ model in GPS-derived IWV estimation. In this assessment, the result of GPS-derived IWV will be assessed with the radiosonde-derived IWV.

Case 1: Available $\mathrm{T}_{\mathrm{M}}$ models

Case 2: Site-specific versus Regional $\mathrm{T}_{\mathrm{M}}$ models Case 3: Site-specific versus Daytime versus Nighttime $\mathrm{T}_{\mathrm{M}}$ models

The root mean square error (RMSE) analysis technique has been implemented to assess the accuracy of $T_{M}$ model. This RMSE analysis is utilized to indicate the closeness of the estimation of GPS-derived IWV to the radiosonde-derived IWV. Lower value of RMSE indicates the most accurate GPSderived IWV to the radiosonde measurement, while higher RMSE suggest otherwise. Equation 25 describes the RMSE equation.

$$
\mathrm{RMSE}=\sqrt{\frac{\sum_{\mathrm{i}=1}^{\mathrm{N}}\left(\mathrm{x}_{\mathrm{GPS}, \mathrm{i}}-\mathrm{x}_{\text {radiosonde }}\right)^{2}}{\mathrm{n}}}
$$

where $X_{\text {GPS }}$ is the estimation of GPS-derived IWV with the $T_{M}$ model and $\mathrm{X}_{\text {radiosonde }}$ is the radiosonde-derived IWV.

\subsection{Case 1: Available $T_{M}$ model}

This study investigates the performance of available $T_{M}$ parameter in Peninsular Malaysia. The entire $T_{M}$ models listed earlier in Table 1 were applied to estimate GPS-derived IWV at all GPS stations. The result for the Case 1 is listed in Table 7.

Table 7: Statistical analysis of GPS station using available $\mathrm{T}_{\mathrm{M}}$ model from Table 1

\begin{tabular}{lllllll}
\hline $\begin{array}{c}\text { GPS } \\
\text { station }\end{array}$ & $\begin{array}{c}\text { Global } \\
\mathbf{1} \\
\left(\mathbf{k g} / \mathbf{m}^{2}\right)\end{array}$ & $\begin{array}{c}\text { Global } \\
\left(\mathbf{k g} / \mathbf{m}^{2}\right)\end{array}$ & $\begin{array}{c}\text { Global } \\
\left(\mathbf{k g} / \mathbf{m}^{2}\right)\end{array}$ & $\begin{array}{c}\text { Tropic } \\
\left(\mathbf{k g} / \mathbf{m}^{2}\right)\end{array}$ & $\begin{array}{c}\text { Tropic } \\
\mathbf{2} \\
\left(\mathbf{k g} / \mathbf{m}^{2}\right)\end{array}$ & $\begin{array}{c}\text { Tropic } \\
\mathbf{3} \\
\left(\mathbf{k g} / \mathbf{m}^{2}\right)\end{array}$ \\
\hline BTNG & 3.010 & 3.624 & 2.984 & 2.860 & 2.937 & 3.079 \\
GETI & 3.972 & 4.666 & 3.940 & 3.745 & 3.861 & 3.239 \\
PEKN & 3.058 & 3.745 & 3.026 & 2.861 & 2.861 & 2.894 \\
USMP & 1.151 & 2.457 & 1.072 & 0.607 & 0.908 & 1.341 \\
\hline
\end{tabular}

Results and discussion of Case 1:

In general, the estimation of GPS-derived IWV is superior by using Tropic model rather than Global model. The Tropic model improved about $1 \%$ - 2\% from Global model. The Global model could be problematic due to several reasons;
1. The warm temperature, low pressure gradient and high abundant of water vapour in low latitude is inadequately considered to reflect the tropical climatic condition.

2. The sparse selection of radiosonde in low-latitude region in Global model is bias to utilize because the sparse interpolation is not representative of the actual water vapour condition.

3. Single equation of Global model consists of cold bias that is contributed from middle and high latitudes to be utilized in low-latitude region. This study found that, the Global 1 and 3 contribute about $6 \mathrm{~K}$, meanwhile the Global model 2 contributes about $10 \mathrm{~K}$.

In comparison of Global model;

The Global 3 has slightly improvement for low-latitude region. This is because more radiosonde stations from the tropical region have been selected and were included to fit the global model. In contrast, the Global 1 is suit for middle latitude because the coverage of radiosonde station ranges between $27^{\circ} \mathrm{N}-65^{\circ} \mathrm{N}$ in Northern America (Yao et al., 2012). Nonetheless, the Global 2 utilized the numerical weather model and reanalysis data to develop the global model. However, less accurate numerical weather model contribute uncertainty to $\mathrm{T}_{\mathrm{M}}$ estimation (Wang et al., 2005).

In comparison of Tropic Model,

The Tropic 1 is most suited to employ in Peninsular Malaysia. It was developed the $T_{M}$ model by utilizing about 10 years periods of radiosonde observations in Taipei. Meanwhile, one year radiosonde observation from Tropic 3 overestimated the $\mathrm{T}_{\mathrm{M}}$ parameter at about $10 \mathrm{~K}$. This indicates that the short period of observation utilized to develop the $\mathrm{T}_{\mathrm{M}}$ model is not suitable because it may consist of systemic bias (Ross and Rossenfeld, 1997).

\subsection{Case 2: Site-specific versus regional $T_{M}$ models}

Few studies demonstrated that the site-specific $\mathrm{T}_{\mathrm{M}}$ model is greater than the regional $\mathrm{T}_{\mathrm{M}}$ model (Liou et al., 2001; Suresh Raju et al., 2007; Singh et al., 2014). The site-specific $\mathrm{T}_{\mathrm{M}}$ model is accurately tuned to site-specific weather condition at single GPS station only which is in contrast to regional $T_{M}$ model that take account of the variability of weather over a large coverage area. Thus, the site-specific $\mathrm{T}_{\mathrm{M}}$ model should give better result compared to regional $\mathrm{T}_{\mathrm{M}}$ model (Bevis et al., 1992).

However, to develop the site-specific $\mathrm{T}_{\mathrm{M}}$ model at each GPS station is likely complicated, especially if there are hundreds to thousands of GPS station within the area. The simple practice is to develop the regional $T_{M}$ model which is based on the combination of several radiosonde observations within the desire coverage area. This regional $T_{M}$ model allows the estimation of GPS-derived IWV at entire GPS station within the coverage area of radiosonde observation.

Thus, the purpose of the Case 2 is to determine the preferred $T_{M}$ model between regional and site-specific. To realize this, the regional $\mathrm{T}_{\mathrm{M}}$ model that has been developed in Equation 16 was used to estimate GPS-derived IWV at the entire GPS stations. Meanwhile, for site-specific, the site-specific $T_{M}$ model was utilized to estimate GPS-derived IWV at the specific location of GPS station in relation to the nearest radiosonde station as listed in Table 2. The result from the Case 2 is shown in Table 8 . 
Table 8: Comparison between regional and site-specific $T_{M}$ model. The RMSE from both models have no significant difference.

\begin{tabular}{cccc}
\hline GPS station & $\begin{array}{c}\text { Regional } \\
\left(\mathrm{kg} / \mathrm{m}^{2}\right)\end{array}$ & $\begin{array}{c}\text { Site-Specific } \\
\left(\mathrm{kg} / \mathrm{m}^{2}\right)\end{array}$ & $\begin{array}{c}\text { Difference } \\
\left(\mathrm{kg} / \mathrm{m}^{2}\right)\end{array}$ \\
\hline BTNG & 2.887 & 2.972 & -0.085 \\
GETI & 3.720 & 3.691 & 0.029 \\
PEKN & 2.890 & 2.878 & 0.012 \\
USMP & 0.631 & 0.615 & 0.016 \\
\hline
\end{tabular}

Result and discussion from Case 2:

1. The range of RMSE in regional model is from 0.631 $\mathrm{kg} / \mathrm{m}^{2}$ at USMP to $3.720 \mathrm{~kg} / \mathrm{m}^{2}$ at GETI. While for sitespecific model the range is from $0.615 \mathrm{~kg} / \mathrm{m}^{2}$ at USMP to $3.691 \mathrm{~kg} / \mathrm{m}^{2}$ at GETI.

2. The USMP has smaller RMSE which is $0.6 \mathrm{~kg} / \mathrm{m}^{2}$. Meanwhile, the GETI station suffers large uncertainty of about 3.691 to $3.720 \mathrm{~kg} / \mathrm{m}^{2}$ in GPS-derived IWV estimation.

3. The distance between GPS and radiosonde stations influence the accuracy of IWV. This study found that the large distance between GPS and the radiosonde stations degraded the accuracy of GPS-derived IWV estimation. The variability of moisture in tropical region is high. The condition of moisture at two different locations could be vary largely if they are far apart. In this study, the distance of USMP is relatively closer to the corresponding radiosonde station (WMKP) compared to other GPS stations. This explains why the USMP has smaller RMSE compared to the rest stations.

4. Site-specific model has slightly reduced the residual of IWV at all GPS stations except BANT. Nevertheless, the improvement from site-specific model is less significant as shown in Table 8.

5. The use of regional model is adequate to support the estimation of GPS-derived IWV at entire GPS station in Peninsular Malaysia. Thus, it is not necessary to develop site-specific model at every GPS station.

\subsection{Case 3: Site-specific versus daytime versus nighttime} $\mathbf{T}_{M}$ Models

The effect of different $T_{S}$ in diurnal has influenced the $T_{M}-T_{S}$ relationship as discuss in Section 3.4. This study also investigated the effect of diurnal variability on the GPS-derived IWV estimates over Peninsular Malaysia. In order to investigate this effect, this study has separately used the temporal $\mathrm{T}_{\mathrm{M}}$ model (daytime and nighttime). For the daytime, the estimation of GPS-derived IWV was achieved by utilizing the daytime $T_{M}$ model, while the nighttime case was by utilizing the nighttime $\mathrm{T}_{\mathrm{M}}$ model. The result for the daytime and nighttime are listed in Table 9 and Table 10, respectively.

Table 9: Comparison between regional, site-specific and daytime $\mathrm{T}_{\mathrm{M}}$ models during daytime observation. The RMSE is slightly reduced by using daytime $\mathrm{T}_{\mathrm{M}}$ model.

\begin{tabular}{cccc}
\hline GPS station & $\begin{array}{c}\text { Regional } \\
\left(\mathrm{kg} / \mathrm{m}^{2}\right)\end{array}$ & $\begin{array}{c}\text { Site-Specific } \\
\left(\mathrm{kg} / \mathrm{m}^{2}\right)\end{array}$ & $\begin{array}{c}\text { Daytime } \\
\left(\mathrm{kg} / \mathrm{m}^{2}\right)\end{array}$ \\
\hline BTNG & 3.107 & 3.109 & 2.893 \\
GETI & 3.422 & 3.381 & 3.396 \\
PEKN & 2.709 & 2.705 & 2.705 \\
USMP & 0.561 & 0.545 & 0.502 \\
\hline
\end{tabular}

Table 10: Comparison between regional, site-specific and nighttime $\mathrm{T}_{\mathrm{M}}$ models during nighttime observation. The RMSE is slightly reduced by using nighttime $T_{M}$ model.

\begin{tabular}{cccc}
\hline GPS station & $\begin{array}{c}\text { Regional } \\
\left(\mathrm{kg} / \mathrm{m}^{2}\right)\end{array}$ & $\begin{array}{c}\text { Site-Specific } \\
\left(\mathrm{kg} / \mathrm{m}^{2}\right)\end{array}$ & $\begin{array}{c}\text { Nighttime } \\
\left(\mathrm{kg} / \mathrm{m}^{2}\right)\end{array}$ \\
\hline BTNG & 3.157 & 3.340 & 2.924 \\
GETI & 3.100 & 3.073 & 3.108 \\
PEKN & 3.067 & 3.047 & 3.064 \\
USMP & 0.697 & 0.681 & 0.690 \\
\hline
\end{tabular}

Result and discussion of Case 3:

1. In overall, the diurnal effect contributed uncertainty of about $1 \%-2 \%$ to the entire GPS-derived IWV in Peninsular Malaysia. There is less significant improvement found by utilizing the daytime and nighttime $\mathrm{T}_{\mathrm{M}}$ models separately.

2. The RMSE in nighttime is higher compared to daytime, this is probably influenced by warm bias (Wang et al., 2005). This diurnal cycle on IWV needed further investigation to reduce the impact of diurnal cycle especially during nighttime.

3. The different of diurnal cycle of $T_{M}$ is about $1 \mathrm{~K}$ which contributed about 1\%-2\% uncertainty to GPS-derived IWV. The effect of diurnal cycle is not critical to GPS meteorological application. Thus, few authors have combined the daytime and nighttime observations to develop a single $\mathrm{T}_{\mathrm{M}}$ model such as demonstrated by Klein Baltink et al., (2000). However, the impact of diurnal cycle might be significant for the study of diurnal cycle of IWV such as demonstrated by Morland et al., (2009) and Ortiz de Galisteo et al., (2011).

\section{CONCLUSION}

Accurate information about atmospheric water vapour is essential for operational weather forecast and climate monitoring especially for tropical communities where large amount of water vapour can be observed. As demonstrated by numerous researchers, the GPS meteorology is capable of estimating the integrated column of water vapour. However, the accuracy of the estimation from GPS meteorology is interrelated to the accuracy of $T_{M}$ model which depends on local spatiotemporal resolution. For improving the estimation of GPSderived IWV, this study estimates the $\mathrm{T}_{\mathrm{M}}$ parameter from four radiosonde stations in Peninsular Malaysia over 2006 to 2008 and hence, develops the $T_{M}$ model based on the relationship of $\mathrm{T}_{\mathrm{M}}$ parameter with respect to $\mathrm{T}_{\mathrm{S}}$ over Peninsular Malaysia. The $T_{M}$ and $T_{S}$ are found to be warm throughout the year with values ranging from about $288-289 \mathrm{~K}$ and $298-299 \mathrm{~K}$ respectively as well as small variation of about $1-2 \mathrm{~K}$. This study developed two types of $T_{M}$ models which are site-specific and regional $\mathrm{T}_{\mathrm{M}}$ model based on the linear regression analysis. It was found that, weak correlation of relationship between $T_{M}-T_{S}$ is due to the diurnal cycle of $\mathrm{T}_{\mathrm{S}}$. By separating daytime and nighttime observation, the $\mathrm{T}_{\mathrm{M}}-\mathrm{T}_{\mathrm{S}}$ relationship was improved from weak $(<0.5)$ to moderate $(>0.5$ to 0.6$)$. However, impact of diurnal cycle in IWV is very small and less significant. This study also investigated the use of $\mathrm{T}_{\mathrm{M}}$ model from Global and Tropic model. The Tropic model was found to be superior for use in Peninsular Malaysia compared to the Global model. 


\section{ACKNOWLEDGEMENTS}

Part of this study was supported by contract research grant from National Space Agency (ANGKASA) from Ministry of Science, Technology \& Innovation (MOSTI) The authors wish to thank the Department of Survey and Mapping Malaysia (DSMM) and the Malaysia Meteorological Department (MetMalaysia) for providing the GPS and meteorological data, respectively.

\section{REFERENCES}

Askne, J. and Nordius, 1987. Estimation of tropospheric delay for microwave from surface weather data, Radio Sci., 22, 379386.

Bevis, M., S. Businger, Herring, T.A., Rocken, C., Anthes, R.A., Ware, R.H., 1992. GPS meteorology - Remote-sensing of atmospheric water vapour using the Global Positioning System, J. Geophys. Res., 97 (D14), 15, 787-15, 801.

Bevis, M., Businger, S., Chriswell, S., 1994. GPS Meteorology: Mapping Zenith Wet Delays on to Precipitable Water. Journal of Applied Meteorology, 33, 379-386.

Boehm, J., Heinkelmann, R., Schuh, H., 2007. Short note: A global model of pressure and temperature for geodetic applications. J Geod 81(10); 679-683.

Businger, S., Coauthors, 1996. The promise of GPS in atmospheric monitoring. Bull. Amer. Meteor. Soc., 77, 5-18.

Dai, A., Wang, J., Ware, R.H., Van Hove, T., 2002. Diurnal variation in water vapour over North America and its implications for sampling errors in radiosonde humidity, J. Geophys. Res., 107(D10), 4090, doi:10.1029/2001JD000642.

Gendt, G., Dick, G., Reigber, C., Tomassini, M., Liu, Y., Ramatschi, M., 2004. Near real time GPS water Vapour monitoring for numerical weather prediction in Germany. Journal of the Meteorological Society of Japan, Vol. 82, No. 1B, pp. 361-370.

Heise, S., Dick, G., Gendt, G., Schmidt, T., Wickert, J., 2009. Integrated Water Vapour from IGS Ground-Based GPS Observations: Initial Results from a Global 5-min Data Set. Ann. Geophys., 27; 2851-2859.

Jin, S.G., Li, Z., Cho, J., 2008. Integrated Water Vapour Field and Multiscale Variations over China from GPS Measurements. Journal of Applied Meteorology and Climatology, 47; 30083015 .

Jin, S.G., Luo, O.F., 2009. Variability and climatology of PWV from global 13-year GPS observations. IEEE Transactions Geoscience and Remote Sensing. 47(7), 1918-1924.

Klein Baltink, H., Derks, H. J. P., van Lammeren, A.C.A.P., Ambrosius, B.A.C., van der Hoeven A.G.A., van der Marel, H., Kleijer, F., Kosters., A.J., 1999. GPS Water Vapour Meteorology. Beleids Commissie Remote Sensing (BCRS), Chapter 2: Water Vapour from GPS Troposheric Delay Estimates, pp. 3-11.

Liou, Y.A., Teng, Y.T., Teresa, V.H., James, C.L., 2001. Comparison of precipitable water observations in the near tropics by GPS, microvawe radiometer, and radiosondes. J. Appl. Meteorology., 40, 5-15.
Loo, Y.Y., Billa, L., Singh, A., 2014. Effect of climate change on seasonal monsoon in Asia and its impact on the variability of monsoon rainfall in Southeast Asia, Geoscience Frontiers, http://dx.doi.org/10.1016/j.gsf.2014.02.009.

Morland, J., Collaud Coen, M., Hocke, K., Jeannet, P., Matzler, C., 2009. Tropospheric water vapour above Switzerland over the last 12 years. Atmos. Chem. Phys., 9; 5975-5988

Musa, T.A., Amir, S., Othman, R., Ses, S., Omar, K., Abdullah, K., Lim, S., Rizos, C., 2011. GPS meteorology in a low-latitude region: Remote sensing of atmospheric water vapour over the Malaysian Peninsula. Journal of Atmospheric and SolarTerrestrial Physics73, 2410-2422.

Nilsson, T., Elgered, G., 2008. Long-term trends in the atmospheric water vapour content estimated from ground-based GPS data. Journal of Geophysical Research, Vol. 113, D19101.

Ross, R. J., Rosenfeld, S., 1997. Estimating mean weighted temperature of the atmosphere for Global Positioning System applications, J. Geophys. Res., 102(D18), 21719-21730.

Schueler, T., Posfay, A., Hein, G. W., Biberger, R., 2001. A global analysis of the mean atmospheric temperature for GPS water vapour estimation. C5: atmospheric effects, IONGPS2001-14th International Technical Meeting of Satellite Division of the Institute of Navigation, Salt Lake City, Utah. Retrieved from http://Forschung.unibwmuenchen.de/ainfo.php?\&id=521.

Shinoda, T., 2005. Impact of the Diurnal Cycle of Solar Radiation on Intraseasonal SST Variability in the Western Equatorial Pacific. Journal of Climate, 18; 2628-2636.

Suresh Raju, C., Saha, K., Thampi, B. V., Parameswaran, K., 2007. Empirical model for mean temperature for Indian zone and estimation of precipitable water vapour from ground based GPS measurements. Ann. Geophys. 25, 1935-1948.

Ortiz de Galisteo, J.P., Cachorro, V., Toledano, C., Torres, B., Laulainen, N., Bennouna, Y., de Frutos, A., 2011. Diurnal cycle of precipitable water vapour over Spain. Q.J.R. Meteorol. Soc. $137 ; 948-958$

Tangang, F.T., Juneng, L., Salimun, E., Vinayachandran, P.N., Seng, Y.K., Reason, C.J.C., Behera, S.K., Yasunari, T. 2008. On the roles of the northeast cold surge, the Borneo vortex, the Madden-Julian Oscillation, and the Indian Ocean Dipole during the extreme 2006/2007 flood in southern Peninsular Malaysia. Geophysical Research Letter, 35; L14S07. doi:10.1029/2008GL033429.

Thayer, D., 1974. An improved equation for the radio refractive index of air, Radio Sci., 9, 803-807, 197.

Ware, R.H., Fulker, D.W., Stein, S.A., Anderson, D.N., Avery, S.K., Clark, R.D., Droegemeier, K.K., Kuettner, J.P., Minster, J., Sorooshian, S., 2000. Real-time national GPS networks: Opportunities for atmospheric sensing. Earth Planets Space. 52, 901-905.

Wang, J., Liangying, Z., Aiguo, D., 2005. Global estimates of water-vapour-weighted mean temperature of the atmosphere for applications. Journal of Geophysical Research, Vol. 110, d21101, doi: 10.1029/2005jd006215.

Wolfe, D.E., Gutman, S.I., 2000. Development of the NOAA/ERL Ground-Based GPS Water Vapour Demonstration 
Network: Design and Initial Results. J. Atmos. Ocean. Technol, $17,426-440$.

Xu, G., Cui, C., Wan, R., Lai., Wan, X., Fu, Z., Feng, G., 2012. Applicability of methods for estimating GPS precipitable water in the Qinghai-Tibet Plateau. Journal of Atmospheric and SolarTerrestrial Physics 89; 76-8.

Yao Y.B., Zhu S., Yue S.Q., 2012. A globally applicable, season specific model for estimating the weighted mean temperature of the atmosphere. J Geod 86(12):1,125-1,135.

Yao, Y.B. Zhang, B., Xu, C.Q., Yan, F., 2014. Improved one/multi-parameter models that consider seasonal and geographic variations for estimating weighted mean temperature in ground-based GPS meteorology. J Geod 88:273-282.

Wayan, S., Iskandar A., 2013. Modeling of Weighted Mean Temperature over the Western Pacific Region to Estimate GPS PWV. Proceeding of the 2013 IEEE International Conference on Space Science and Communication (IconSpace), 1-3 July 2013, Melaka, Malaysia. 